\title{
The Effect of Evaporative Formations in Increasing the Salinity of the Water Resources in Mahdasht-Eshtehard Region (Iran)
}

\author{
Naser Ebadati ${ }^{*}$, Hoseyn Yousefi² \\ ${ }^{1}$ Department of Geology, Islamic Azad University, Islamshahr Branch, Islamshahr, Iran \\ ${ }^{2}$ Department of Renewable Energy and Environment, Faculty of New Sciences and Technologies, Tehran University, Tehran, Iran \\ Email:^drebadati@iiau.ac.ir
}

How to cite this paper: Ebadati, N. and Yousefi, H. (2016) The Effect of Evaporative Formations in Increasing the Salinity of the Water Resources in Mahdasht-Eshtehard Region (Iran). Journal of Geoscience and Environment Protection, 4, 1-12.

http://dx.doi.org/10.4236/gep.2016.49001

Received: July 13, 2016

Accepted: August 29, 2016

Published: September 1, 2016

Copyright (c) 2016 by authors and Scientific Research Publishing Inc. This work is licensed under the Creative Commons Attribution International License (CC BY 4.0).

http://creativecommons.org/licenses/by/4.0/ (c) (i) Open Access

\begin{abstract}
Considering the underground water resources salinity problem in Mahdasht to Eshtehard region of southern Alborz Province, we attempted to deal with the relationship between the water sources features especially salinity with the geology of the mentioned range in terms of petrology and structural properties. For this purpose after determining the study range, field investigation was performed to identify the geological formations and the distribution thereof as well as the faults locations using existing geological maps. Using a fourteen year period statistics (2009-2014), the static water table, the discharge rate, annual exploitation and the plain's underground water level elevation (GIS) were analyzed and evaluated. Water samples were taken from 18 wells and chemical analysis determining the quality of water was used. The concentration contour maps of chloride, sulfate, sodium and total soluble solids together with the faults performance analysis showed that the highest salinity concentration relates to northeastern part of the plain. Concentration and qualitative results, the regional water quality can be classified in moderate to disagreeable in terms of potability and saline for agricultural use. The study findings showed that the high evaporative masses' erosion rate and gypsum and saline sediment transport from the northeast Neogene formations have developed saline field in the plain and immethodical exploitation of water sources has considerably reduced the water quality and increased the salinity.
\end{abstract}

\section{Keywords}

Water Quality, Salinity, Mahdasht, Eshtehard, Hydrogeology

\section{Introduction}

The geological structures play major controlling role in determining the groundwater 
composition [1] [2]. The groundwater quality in different areas adjacent to evaporative formations indicate that large variety of formations, geological structures and hydrological factors are involved [3] [4]. The geological and hydrochemical analysis and decomposition of water well samples determine that the existence of evaporative formations is greatly effective in the water quality in best part of such areas [5]. The under study area from the geomorphology perspective is divided into two mountainous and flat lands, with the salt marsh plains constituting the major part of the flat lands that cover the northern part of the study area in the form of a narrow band. Eshtehard County in terms of the land appearance is comprised of the mountainous and plain areas. Eocene volcanic rocks have created the southern heights. The main fault regions lie in the separative boundary between the highlands and lowlands. The overthrust fault of Mardabad which is located on the border between the northern heights and Eshtehard plain has caused the overthrust of the northern heights (Neogene clastic-evaporative units) on the Quaternary sediments of the plain [6]. From the structural geologic perspective the heights of the region are in anticline form, while Mahdasht plain of Eshtehard takes syncline form. The aquifer length in this range is about $27 \mathrm{Km}$ and its width in regions close to the eastern boundaries, western boundaries and the areas in between about $9 \mathrm{~km}$ respectively. The aquifer area in the study range is about $240 \mathrm{Km}^{2}$. From the structural geology perspective, the aquifer bed rock is in synclinic form above which the rivers' alluviums and flood plains of the present era have been deposited [7]. The bed rock nature is of Plio-Quaternary sedimentary depositions constituting from weak conglomerates with sand, silt and clay interlayers that lie with unconformity on the Neogene sedimentary depositions. The average depth of the bed rock depth is about $125 \mathrm{~m}$. Figure 1 shows a satellite image of the study area where general feature semiarid area in western parts of the erosion indicator and low vegetation can be seen. And in the eastern part of the region is urban development.

The geologic settings of the area include the Eocene volcanic formations, Neogene clastic-evaporative formations and Quaternary depositions. The evaporative sediments of the area consist of the salt, gypsum and marl. The volcanic rocks (mostly basaltic) have created southern heights of Eshtehard. Nature of the area bed rock is of Plio-Quaternary sedimentary depositions consisting of weak conglomerates with sand, silt and clay interlayers which lie with unconformity on the Neogene sedimentary depositions (red marl, gypsum and salt interlayers, sandstone, silstone and thin lime). Neogene sediments are weak and easily erodible and besides, the weather conditions have also formed the morphology of the area in the long run through speeding up of the weathering and erosion of the easily erodible units [6]. For this reason the Neogene rocks are observed in the low rise areas. Most of the Quaternary depositions of the area have been formed by young low rise alluviums of the current era. These depositions are coarse grained near the southern and northwestern heights, but towards the center and northern areas of the plain the silt and clay particles prevail (Figure 2).

The most important faults of the study area are Eshtehard overthrust fault, Mardabad fault, Sariyal fault and southwestern limb and fault of the range which is most likely the 


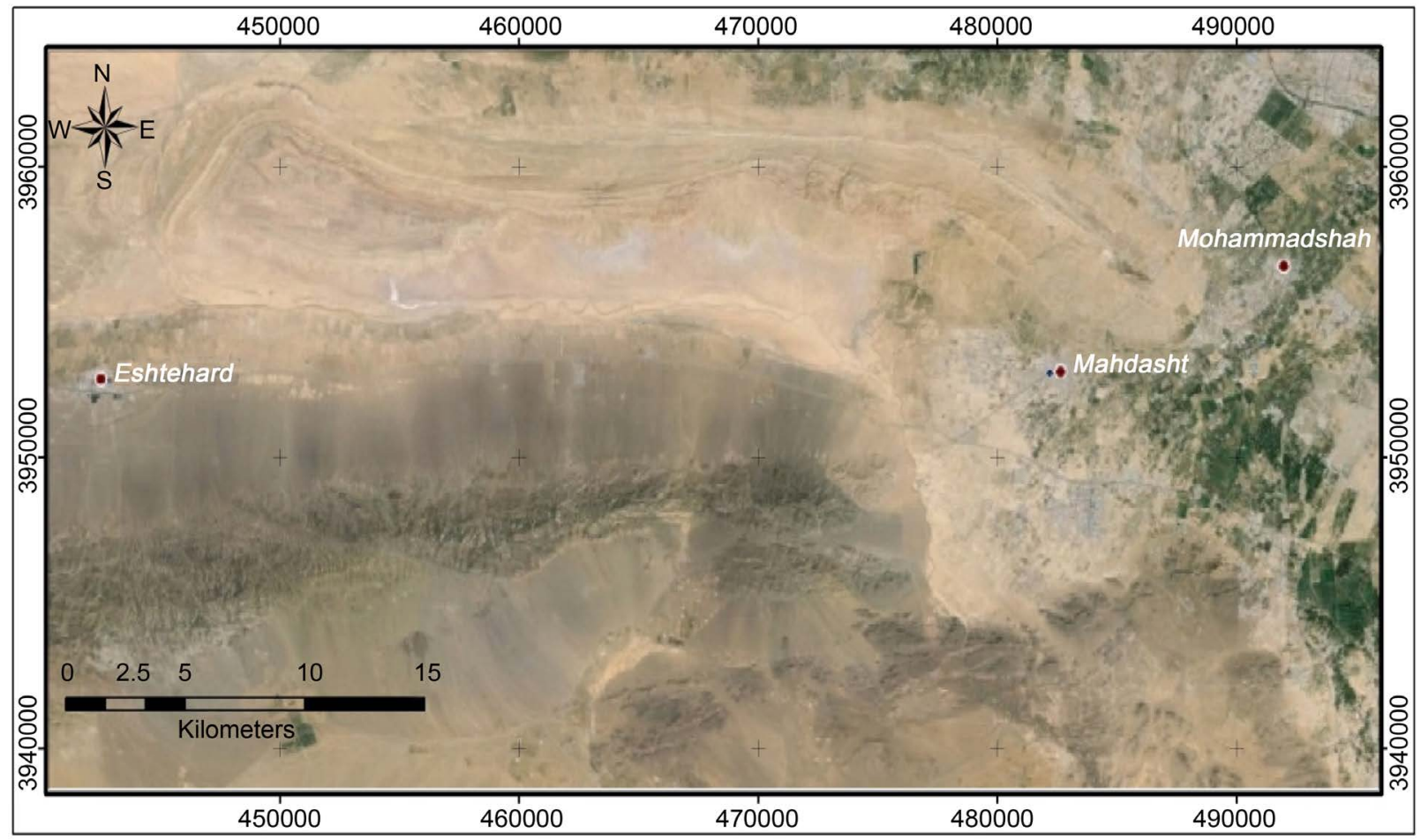

Figure 1. Satellite image Mahdasht-Eshtehard aquifer and the status of topographic features in the area.

continuance of Gomrokan fault. Eshtehard and Mardabad overthrust faults that tend northward with slop are in fact the northern border of the aquifer. Due to this faulting the Neogene clastic evaporative units (shale, marl, with gypsum interlayer) have been thrusted on the present Quaternary units and considering the flow direction of the groundwater, these faults play the feeding role of the aquifer. Considering the change trend of the elements' concentration contour maps, this fault has been effective in the decrease of the groundwater quality in the northeast of the area [8].

\section{Materials and Methods}

In order to determine the distribution of rocks influential on the increase in the content of solvents and salinity of water sources, initially through collecting the geological and hydrogeological data [9] and field studies the geological maps were prepared and thereby the formations effective in the water sources' quality were identified and besides, the tectonics and geological structures for specifying the quantitative changes of water were studied [10]. In the next stage the water wells existing in the area were identified and their locations were mapped and all the relevant basic data were entered into the geographical information system (GIS). Using a 14-year period statistics (2001-2014), the static water table, the annual depletion and exploitation and underground water level elevation (GIS) was analyzed (Table 1). Also through sampling of the selected wells' waters and using figures and results of chemical analysis of the samples as well as the available data of 18 Piezometer wells the maps and different water qualitative graphs were plotted and the qualitative interpretation of the groundwater sources was 


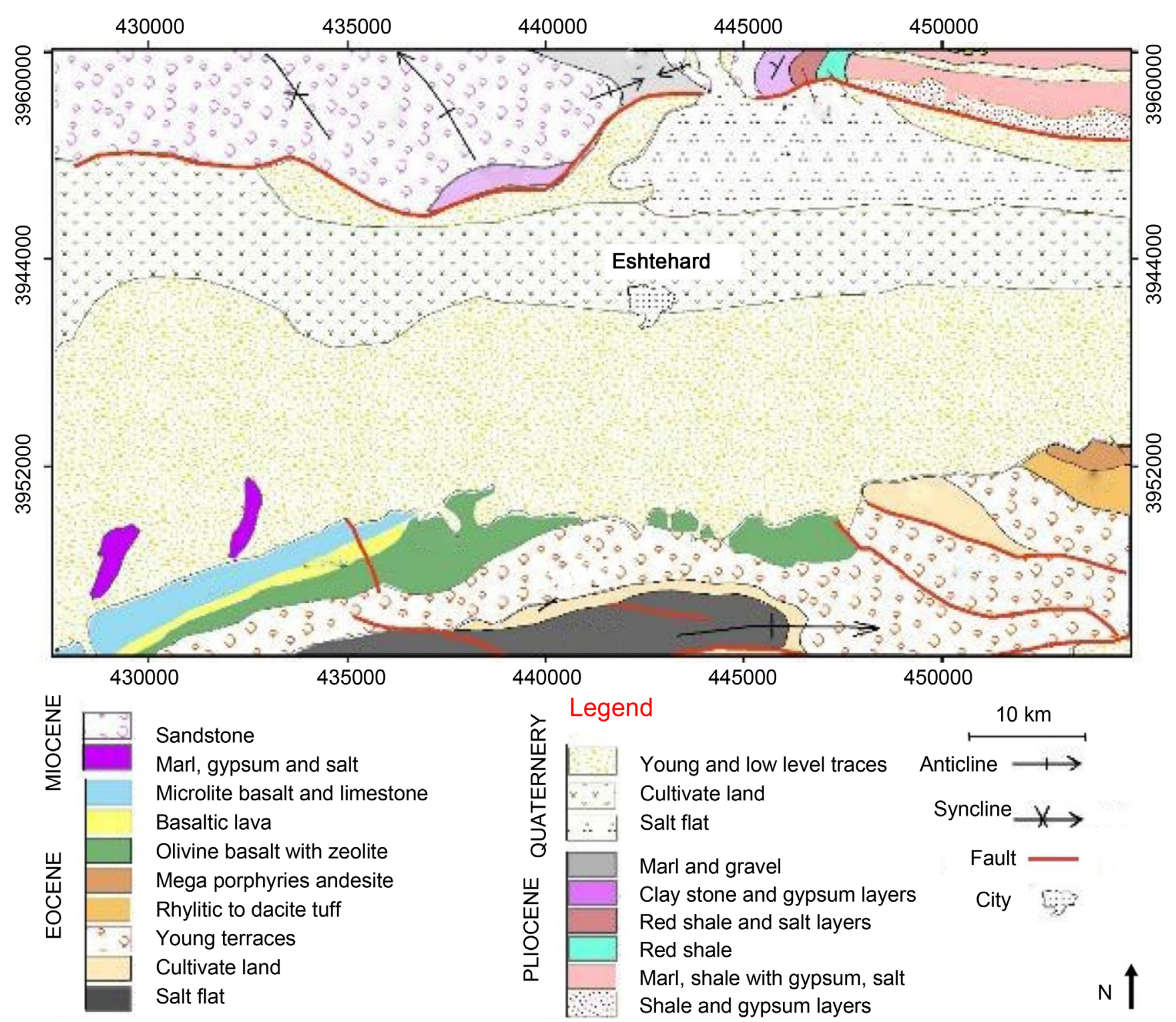

Figure 2. Geological map of study area.

performed. Considering the statistics and the wells' exploitation and consumption type, the highest usage of the water sources relates to the agricultural use [11]. Plotting the ground water discharge maps, it was revealed that the highest consumption occur around the central part of the plain; hence the effects of ground water flow as well as the decrease in the amount of the entry water into the plain table in changes of the solvents and salinity amounts were analyzed [12] [13].

\section{Hydrology and Hydrogeology}

Investigation of the regional hydrology revealed that the saline river entering from the northern evaporative saline heights into the study area and its flow path from the north of to the outer eastern parts conveys through drainage huge amount of solvents with 
Table 1. The results and the concentration of elements in the sampling wells.

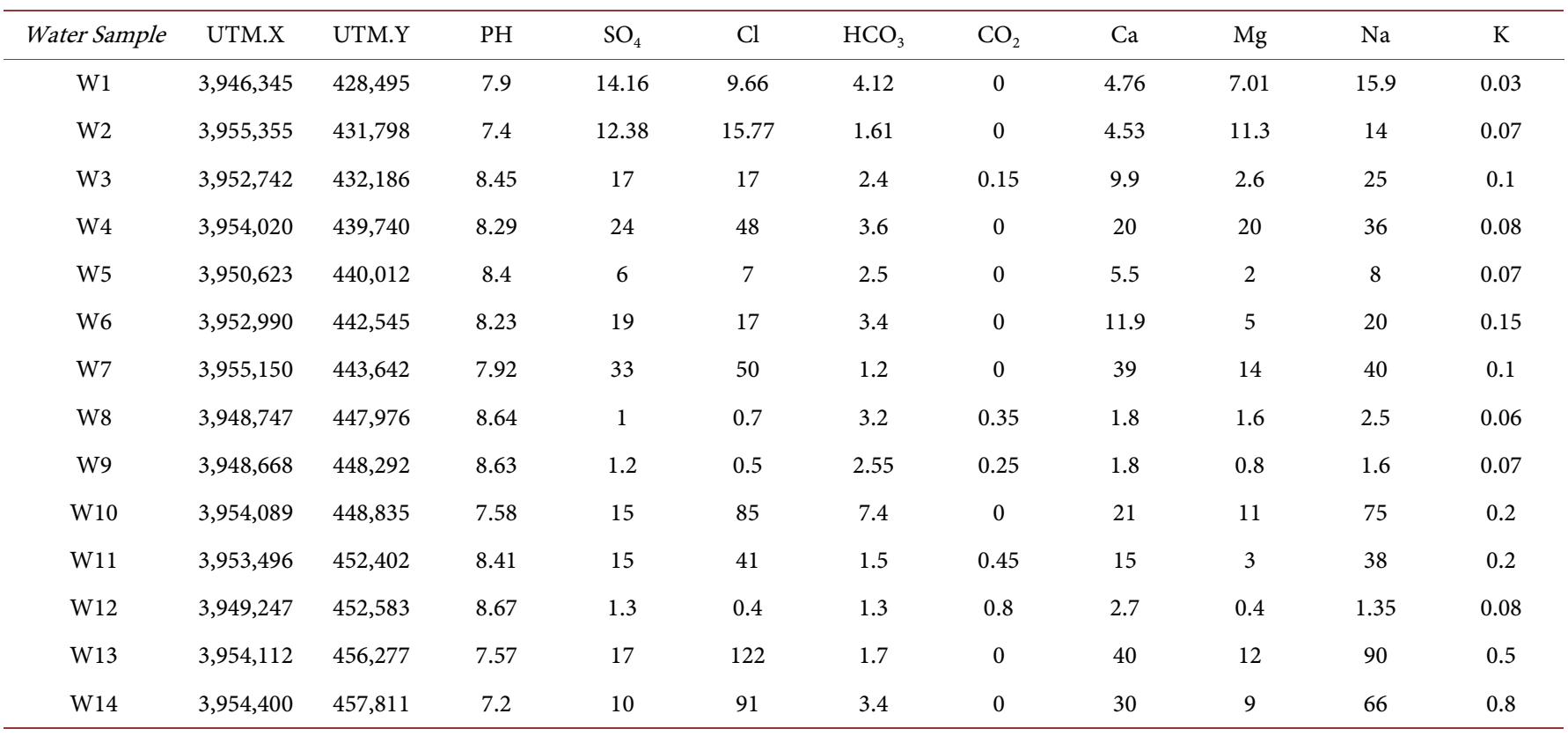

itself into the area soil and aquifer. Also in the study area due to the presence of topographic slope, the streams flow from the northern and southern heights towards the saline river and surface and ground waters are drained from the west to the east directions by this river [14]. Considering the sediments are small grain size and low depth of nonsaturated. Thickness in the region, the concentration is high in the sediments and has caused low quality of the water in the area. Analysis of the ground water level elevation shows that the saline river in this range plays the discharging role of the aquifer, and this hydraulic relationship between the river and the groundwater causes mixing of the solvents in the groundwater and ultimately decreases the underground water sources quality in the understudy area.

The saline field which is the product of the erosion of clastic evaporative depositions of northern heights contains abundant small grain sized solvents and cannot develop an exploitable aquifer due to inadequate quantitative and qualitative conditions. These areas of the aquifer belong to the relatively good class in terms of the yield due to coarse grained alluvial depositions and low clay content percentage. Most of the wells and aqueducts in the area are focused in the center and northern half of the plain which due to the level drop caused by unauthorized over exploitation are increasing the concentration of solvents and decreasing the quality of water sources. Considering the ground water discharge contour map of the plain the highest amount of depletion and exploitation of the aquifer relates to the median part of the plain.

Flow direction of underground water: Considering the ground water flow direction map, the southern and northern heights are playing the feeding role of the aquifer. Analyzing the static groundwater level contour maps showed that the highest drop relates to the center of the plain; also groundwater depletion contour maps due to over exploitation show that the highest drop of the ground water table relates to the center 
of the plain. These two evidences show that by the increase in the drop of the groundwater level in the understudy area, the overall slop of the underground water level is changed and the highest slope is seen towards the center of the plain. The decrease of the underground water level in northern part of the plain is due to the natural drainage of the ground water by the saline river in the vicinity of the saline field.

\section{Determining the Qualitative Parameters Relevant to the Solvents and Water Salinity}

The natural factors affecting the area water quality are the presence of clastic evaporative formations in the northern heights and saline field in the northeast of the area. Therefore, through depicting the map of clastic evaporative formations as well as the concentration contour map of the elements in the ground water sources the relationship between them was investigate. Through investigating the concentration change trend of the elements existing in the study area, the origin of the elements contained in the area water sources was evaluated. The following section deals with the description of some important parameters effective in the quality of the area waters:

$\mathrm{Cl}$ : The Chloride concentration level is high in the northeast part of the plain which is the sign for salinity of the groundwater around the area. Since the $\mathrm{Cl}$ ion is not affected by the chemical processes like the absorption and ion exchange, hence it can be used as the unchanging tracker. The $\mathrm{Cl}$ change trend in the plane is from the north towards the center and eastern parts of the plain. This trend conforms to the saline field location along with the saline river. The drainage of the saline river from the clasticevaporative rocks of the northern heights, fine particle sediments in the area and low depth of the unsaturated thickness in this section (the ground water evaporation region) constitute the key factors in concentration of $\mathrm{Cl}$ element in the area. The origin of $\mathrm{Cl}$ ion concentration in the area has been the saline field in the northeastern part of the plain. Considering the above graph the $\mathrm{Cl}$ content of the area in Eshtehard plain is higher than the WHO standards. The maximum permissible $\mathrm{Cl}$ content in the WHO standards for the potable water is $16.8 \mathrm{meq} / \mathrm{l}$. The above graph shows an increasing trend in the $\mathrm{Cl}$ ion concentration level which is the highest level of $\mathrm{Cl}$ at the year 2010 .

Na: The highest level of Sodium concentration $75 \mathrm{meq} / \mathrm{l}$ has been recorded for the eastern and western parts of the understudy area. Saline waters of the area and agricultural activities area the increasing factors of this ion amongst others. The Na content of the saline waters is concentrated due to the cation exchange with the soil and water elements $(\mathrm{Ca}$ and $\mathrm{Mg})$. The Sodium content in northern regions of the area is higher than other parts.

$\mathrm{SO}_{4}$ : The highest concentration of Sulfate is observed around the saline field $\left(\mathrm{Q}^{\mathrm{ls}}\right)$ and the gypsum containing formation $\left(\mathrm{M}^{\mathrm{g}, \mathrm{s}}\right)$, indicating that these evaporative units are the origin of the sulphate ions in the area. The $\mathrm{SO}_{4}$ ion amount expands towards the center and western parts of the study area. As can be seen from the above graph, the $\mathrm{SO}_{4}$ content in the study area of Eshtehard plain from the year 2003 to 2005 compared with the maximum permissible amount of $\mathrm{SO}_{4}$ for potable water in $\mathrm{WHO}$ standard has 
been $8 \mathrm{meq} / \mathrm{l}$ which is suitable for drinking water and afterwards, such concentration has increased at 2005 to 2010.

The waters have more suitable status in terms of $\mathrm{HCO}_{3}$ and $\mathrm{Mg}$ content compared with other ions. Given the sample analysis results, the best and worst water quality belongs to the southern and northern areas respectively. Analysis of the Wilcox graph revealed that the northern regions belong to the worst Wilcox class and are unsuitable for agricultural consumption. Water of the regions close to Eshtehard City has higher salinity and electrical conductivity that makes them unsuitable for agricultural use.

Electrical conductivity (EC): According to the Figure 4 the highest EC level has been focused on the northeastern parts of the study range. The general trend of the EC increase is from the north to the south which is due to the increase in the soluble elements' content in the ground water sources of this part of the understudy area. The groundwaters of the northeastern part of the study range in the vicinity of the saline field are considered as non-potable as per the international EC standards. In southern and western parts and also to some extent in central parts of the plain the groundwaters are suitable in terms of EC content. Considering the above graph, the average amount of EC content in overall under study area of Eshtehard plain are higher than the WHO standards, showing the high amounts of the water sources' solvents in the area. The maximum amount of EC in WHO standards for drinking water is $2000 \mathrm{~m} \mu / \mathrm{cm} \mathrm{[15]}$ [16]. Considering the above graph an increasing trend in the amount of EC is observed from the year 2001 to 2013 (Figure 3).

TDS: The highest amount of total dissolve solid (TDS) in the range of understudy area can be found in the northern and northeaster parts. A general trend is north to center of the plain. In gyps and marl regions the cations and anions' concentration is increased due to the presence of Calcium and Magnesium minerals and consequently the TDS amounts are also increased. Based on the water quality classification standard and in terms of TDS, the southern and western parts of the plain belong to the soft water class but the northern and eastern parts can be classified as belong to brackish regions.

\section{Result and Discussion}

\section{Investigation of Agricultural Water Quality}

Given that the southern heights of the study area are considered as the feeding zones of the aquifer, having been constituted from relatively permeable formations, it would be natural for the groundwaters fed by this source to contain bicarbonated type clastic, meanwhile the volcanic heights being also effective in determining the water type of the area. This zone has an agreeable water quality. Most of the northern parts of the plain are of Sodium chloride type which is due to the groundwater feeding by the northern heights. Given that that the prevailing lithology of the heights is evaporative depositions, the water quality of the region is improper and (given the high solubility of such depositions) the water contains high amounts of solvents. In southwestern parts of the 


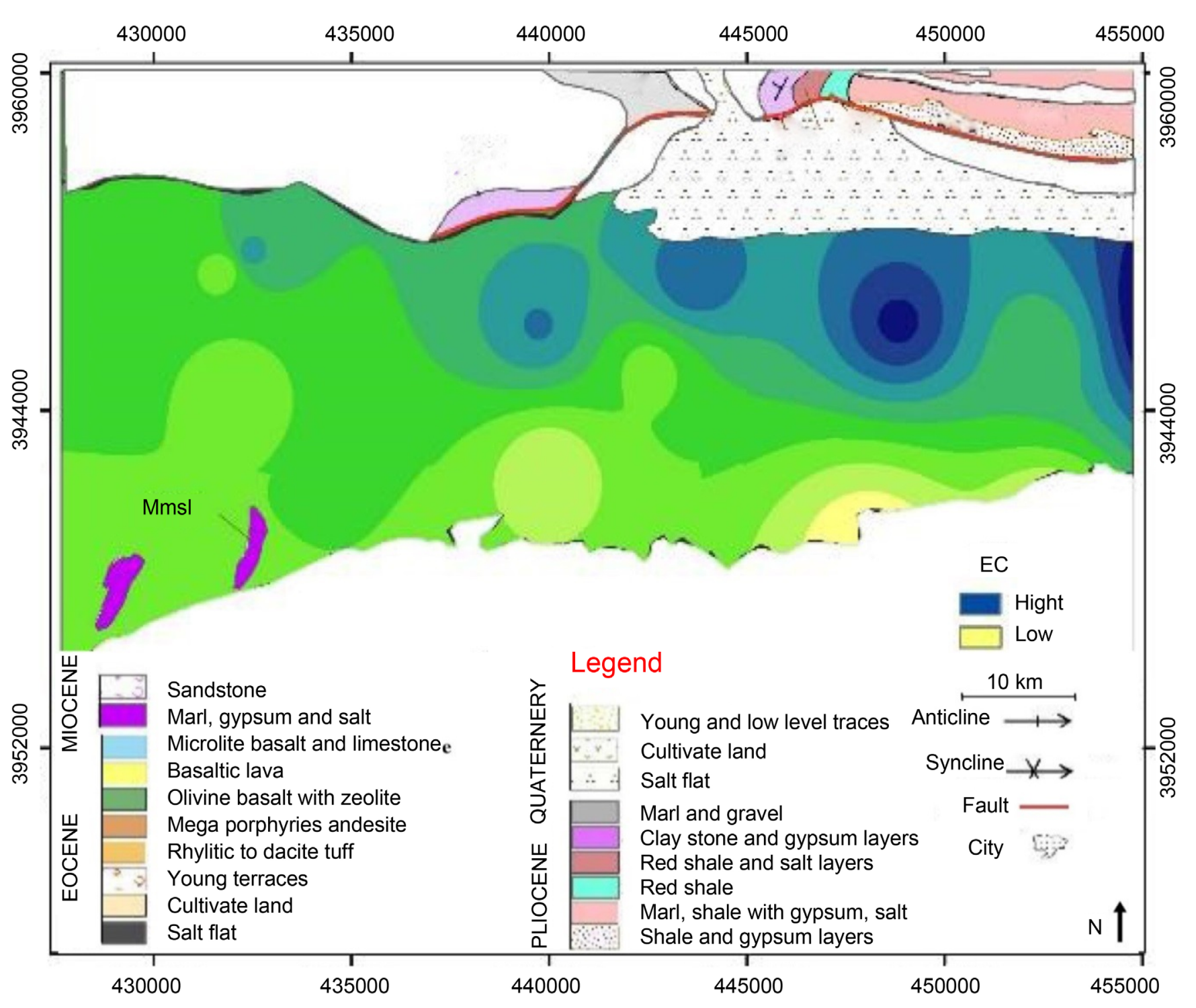

Figure 3. Modeling map of EC in the plain area studies.

area (W1) the water is of sulphate sodium type due to the existence of small areas of evaporative layers (marl, gypsum, salt) between the Quaternary sediments. Considering the Wilcox diagram of the selected Well No. 13, the water of southern regions of Eshtehard plain has higher quality in terms of the agricultural use (Figure 4). The reason being that such wells are located farther from the saline river and the evaporative saline field, and in the meantime, the surroundings being consisted of sand sediments close to the southern volcanic heights. The northern regions belong to the worst Wilcox class and the water in these regions is not suitable for agricultural use at all the high concentration of sodium and the EC level in the region is due to solubility of saline evaporative formation and feeding by the saline river. Also the decrease in unsaturated thickness and evaporation of the groundwater in the area can be the effective factor in increasing the soluble solvent content of the groundwaters. Unsuitable quality of the well No. 


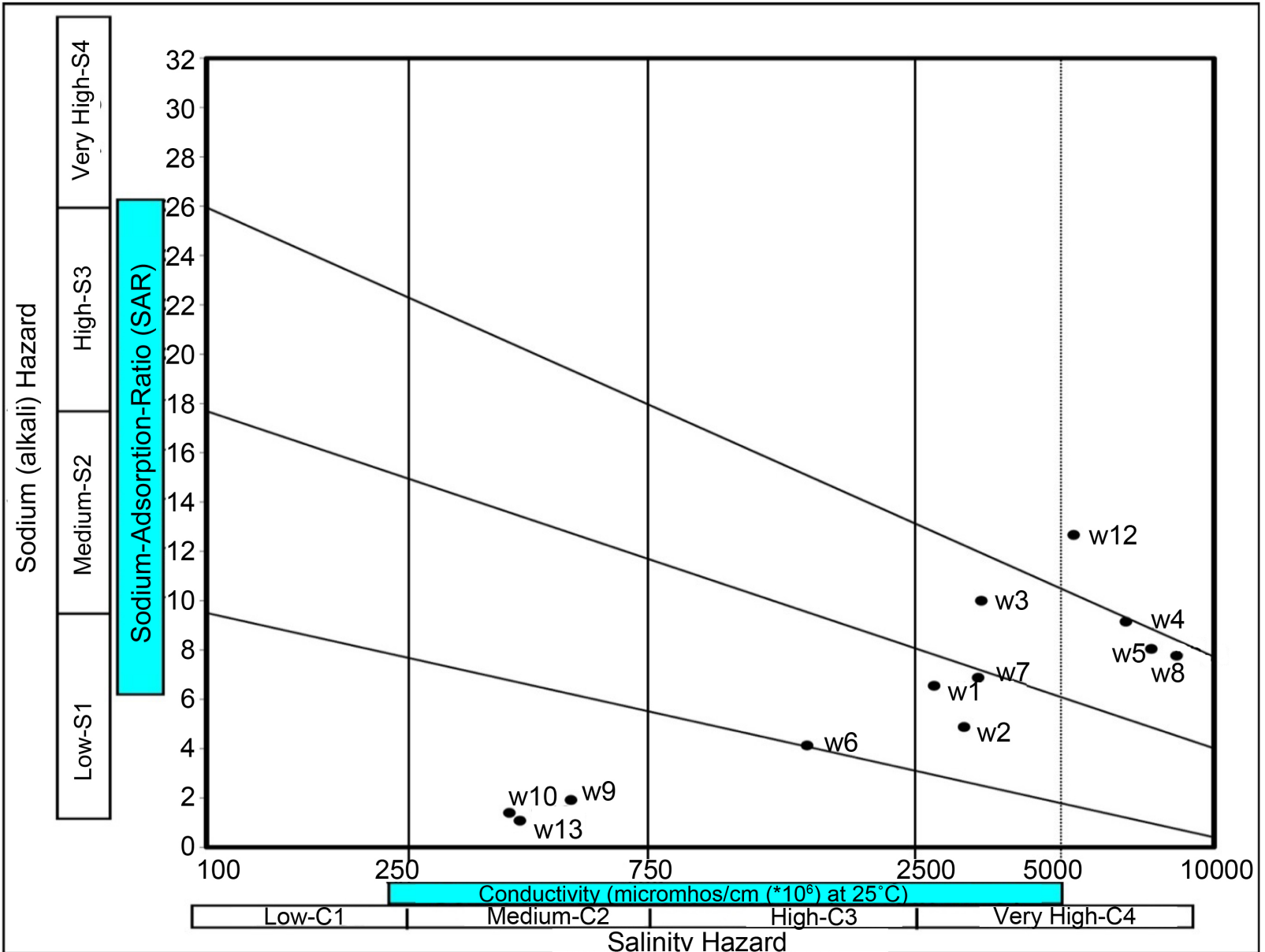

Figure 4. Wilcox diagram of groundwater in the plain area Mahdasht-Eshtehard with the base of sampling wells.

W3 is due to the drop of water level and increasing the concentration of soluble.

Determining the $S A R$ parameter for agricultural consumptions: The Sodium absorption rate $(S A R)$ means absorption of water soluble $\mathrm{Na}$ ion as a result of the exchange of water cations in soil as per the increase and decrease of $\mathrm{Ca}$ and $\mathrm{Mg}$ cations and can be obtained from the following relationship:

$$
S A R=\mathrm{Na} / \sqrt{(\mathrm{Ca}+\mathrm{Mg}) / 2}
$$

$S A R, \mathrm{Na}, \mathrm{Ca}$ and $\mathrm{Mg}$ concentration meq/l.

The formula (1) refers to the calculation of agricultural consumption water [9] [17]. Considering the above relationship the conclusion can be drawn that as per the increase in the $\mathrm{Ca}$ and $\mathrm{Mg}$ cations in water, the Sodium absorption power of the soil is decreased and by the decrease of such cations the power of Sodium absorption in soil is increased. The increase in Na content of the soil causes stiffness of the soil due to cation exchange and makes the growth of the plants harder [18]. The highest level of SAR relates to the eastern and northwestern part of the plain. Based on the irrigation water specifications in the study area in terms of the SAR, the water can be classified as very good to moderate. The $\mathrm{Na}$ content of the water in southern parts of the plain is low and is variable 
towards the north and east of the study range.

The Roodshor River with north-south direction of flow is one of the most important surface water sources in Eshtehard plain which has been transformed into a seasonal river due to dryness during warm months of the year. This river locates in the northeastern part of the study area, originating from the northern heights and flowing in west-east direction in the understudy area. Due to the geological formations existing in the flow path of the river, its water quality in terms of quality classification belongs to the non-drinkable class for the household consumptions and improper for the agricultural and livestock consumptions. This has caused that the water quality of the groundwater sources in northern margin of the plain close to the clastic evaporative heights to be lower than the other regions [11]. As was mentioned before, the hydrogeological investigations and the depicted groundwater maps showed that Mahdasht aquifer in southern and northern borders of the plain plays the feeding role of the aquifer. The northern border of the aquifer is in fact a fault boundary that because of this faulting the Neogene clastic evaporative units (shale, marl, with gypsum interlayer) have been thrusted over the Quaternary units of the present era and it seems like that this fault (Mardabad fault) plays the feeding role of the aquifer. Investigation of the static groundwater level contour maps showed that the highest drop has occurred in center of the plain; also the survey of the groundwater discharge contour maps due to over exploitation reveals that the highest drop of the water elevation of the groundwater table belongs to the center of the plain. These two evidences show that by the increase in the drop of the groundwater level in the study area, the overall slope of the underground water level has changed and the highest slope is observed towards the center of the plain. The decrease in the underground water level in the northern part of the plain is due to the natural discharge of the ground water by the saline river abutting the saline field.

Based on the qualitative analyses of the water sources, the prevailing type of the underground waters in the southern parts of the study range is carbonate calcium that locally transforms into bicarbonate sodium while in the middle and northern parts the prevailing type of underground waters becomes sodium chloride. Electrical conductivity (EC) rate in the northern and eastern part of the plain is higher than that of the other parts which is due to the increase in the amount of solvents in northern part of the plain which is affected by the soluble saline evaporative layers in the north of the plain. The high concentration of $\mathrm{Cl}$ in northern and northeastern parts of the plain is due to the presence of saline field in the area. The underground waters in the area are rich of $\mathrm{Cl}$ and $\mathrm{Na}$ ions and these two ions are the main salinity cause of the water. The high EC rate also confirms the high salinity of the area. Assessment of $\mathrm{Cl}$ and $\mathrm{SO}_{4}$ concentration and EC rate in the 14 years period average (2001-2014) showed that the $\mathrm{Cl}$ and Ec concentration has increased in the area, but the $\mathrm{SO}_{4}$ ion does not show increasing trend. The reason for the increase in the $\mathrm{Cl}$ content of the understudy area is its high solubility, the existence of saline field in the northeast of the range, the drainage by the river and streams as well as the drop of the ground water level due to immethodical 
exploitation of water sources. The simultaneous increase in EC and $\mathrm{Cl}$ rate may be confirmatory to this issue. The increase in the $\mathrm{Cl}$ content in addition to the above factors can be due to the fine grain sediments and low depth of the unsaturated thickness of the area. For these layers due to small particle size of their contents and their low unsaturated thickness induce volatilization of ground waters and increase in the amount of solvents. The $\mathrm{Na}$ ion also has high concentration in the area due to its close geochemical behavior to the $\mathrm{Cl}$ ion.

\section{Conclusions}

1) Geological formations in the area that are of evaporative saline type contain gypsum and salt minerals, mainly have formed vast saline layers and fields in the northern parts of the area due to erosion.

2) The presence of saline river in the area and the northern streams having hydraulic relationship with the aquifer; this river by drainage of the Neogene clastic evaporative units in upstream of the area and by depositing the elements of these units in the sediments of the region heightens the anions and cations' concentration in the aquifer of the area.

3) Low feeding of the area and excessive exploitation of the groundwater has caused decrease of the hydraulic slop of the groundwater, making the aquifer incapable of effective discharging of the solvents.

4) The presence of small grain size layers in the northeast of the area which due to lower permeability and cation exchange phenomenon has caused higher concentration of the solvents; the above are the factors involved in decrease of the table porosity and higher salinity of the area waters.

\section{Acknowledgements}

I would like to express our sincere thanks to the respected management of department of Quality Control of Tehran Water and Sewage Company for facilitating the ground for this study and compilation of this paper.

\section{References}

[1] Gasemi, A., Lashkaripour, G., Baniasdi, A., Hasanaki, M. and Nematollahi, M. (2013) Assess the Impact of Geology on the Quality of Water Resources in the Catchment Area Shorlogh Sarakhs, Khorasan Razavi Province. 8th Conference of the Geological Society of Environmental Engineering, No. 1, 1406-1408.

[2] Karimi, H. and Asgari, P. (2011) Evaluation of Geological Formations on Groundwater Quality Plain Porch, Ilam. 15th Conference of the Geological Society of Iran, Tehran, Geological Society of Iran and Tarbiat Moallem University, No. 1, 56-67.

[3] Lashkari, M. and Lashkaripour, G. (2011) Quality Assessment of Iranshahr Groundwater and Water Quality Effects of Geological Formation. Proceedings of the 3 rd Conference of Earth Sciences, Geological Survey of Iran, 1-7.

[4] Gazzaz, N.M., Kamil Yusoff, M., Zaharin Aris, A., Juahir, H. and Firuz Ramli, M. (2012) Artificial Neural Network Modeling of the Water Quality Index for Kinta River (Malaysia) 
Using Water Quality Variables as Predictors. Marine Pollution Bulletin, 64, 2409-2420. http://dx.doi.org/10.1016/j.marpolbul.2012.08.005

[5] Kanakoudis, V., Tsitsifli, S. Samaras, P. and Zouboulis, A. (2015) Erratum to: Water Pipe Networks Performance Assessment: Benchmarking Eight Cases across the EU Mediterranean Basin. Water Quality, Exposure and Health, 7, 109.

[6] Aganabati, A. (2004) Geological of Iran. Geological Survey of Iran, 556 p.

[7] Ranjbar, M. (2009) Factors Affecting the Subsidence Plain Eshtehard. Iranian Journal of Iran Geography, 6, 4-23.

[8] Yosefi, M., Emami, M. and Alavi, M. (2000) Geological Map and Reports Square Eshtehard, Scale 1:100,000. Geological Survey and Mineral Exploration of Iran No. 1.

[9] Sarani, N., Soltani, J., Sarani, S. and Moasheri, A. (2012) Comparison of Artificial Neural Network and Multivariate Linear Regression Model to Predict Sodium Adsorption Ratio (Case Study: Sistan River, Iran). International Conference on Chemical, Ecology and Environmental Sciences (ICEES 2012), 17-18 March 2012, Bangkok, Vol. 1, 130-134.

[10] Masoudi, M., Patwardhan, A.M. and Gore, S.D. (2006) A New Methodology for Producing of Risk Maps of Soil Salinity, Case Study: Payab Basin, Iran. Journal of Applied Sciences and Environmental Management, 10, 9-13. http://dx.doi.org/10.4314/jasem.v10i3.17312

[11] Ebadati, N. and Sepahvandi, S. (2015) Role of Geological Structures and Lithology in the Quantitative and Qualitative Changes of Eshtehard Aquifers. Iranian Journal of Echo $\mathrm{Hy}$ drology, 2, 117-128.

[12] Murad, A., Mahgoub, F. and Hussein, S. (2012) Hydrogeochemical Variations of Groundwater of the Northern Jabal Hafit in Eastern Part of Abu Dhabi Emirate, United Arab Emirates (UAE). International Journal of Geosciences, 3, 410-429.

http://dx.doi.org/10.4236/ijg.2012.32046

[13] Samy, I. and Mohammed Mostafa, M. (2012) Topographic Attributes Control Ground Water Flow and Groundwater Salinity of Al Ain, UAE: A Predication Method Using Remote Sensing an GIS. Journal of Environment and Earth Science, 2, 1-14.

[14] Sepahvandi, S. (2015) The Effect of Geology and Structural Factors in the Quantitative and Qualitative Changes Eshtehard Water Resources. Environmental Geology Master's Thesis, Islamic Azad University Science and Research Branch, 132 p.

[15] World Health Organization (WHO) (1993) Study Protocol for the World Health Organization Project to Develop a Quality of Life Assessment Instrument (WHOQOL). Division of Mental Health, Switzerland, Special Report, Quality of Life Research, 2, 153-159. http://dx.doi.org/10.1007/BF00435734

[16] W0rld Health Organization (WHO) (2004) Guidelines for Dring Water WHO. Wuliy, Vol. 102 and 103, WHO, Geneva.

[17] Nielsen, D.M. (2006) Practical Handbook of Environmental Site Characterization and Ground-Water Monitoring. 2nd Edition, Taylor \& Francis Published, United States of American, $1317 \mathrm{p}$.

[18] Sedagat, M. (2003) Earth and Water Source (Hydro Geology). Payam Noor University, Iran, $385 \mathrm{p}$. 
Submit or recommend next manuscript to SCIRP and we will provide best service for you:

Accepting pre-submission inquiries through Email, Facebook, LinkedIn, Twitter, etc. A wide selection of journals (inclusive of 9 subjects, more than 200 journals)

Providing 24-hour high-quality service

User-friendly online submission system

Fair and swift peer-review system

Efficient typesetting and proofreading procedure

Display of the result of downloads and visits, as well as the number of cited articles

Maximum dissemination of your research work

Submit your manuscript at: http://papersubmission.scirp.org/ 